\title{
Insulin analogues differently activate insulin receptor isoforms and post-receptor signalling
}

\author{
L. Sciacca • M. F. Cassarino • M. Genua • G. Pandini • \\ R. Le Moli $\cdot$ S. Squatrito $\cdot$ R. Vigneri
}

Received: 26 February 2010 / Accepted: 19 March 2010/Published online: 28 April 2010

(C) Springer-Verlag 2010

\begin{abstract}
Aims/hypothesis Five insulin analogues, with modified insulin-like molecular structures, are currently approved for treating diabetic patients. They activate cell signalling and biological responses via insulin receptor isoforms (IR-A and IR-B), each having specific characteristics for eliciting cell responses. The molecular and biological effects of these analogues on receptor isoforms in comparison to native insulin are not well defined, and their effects on the IGF1 receptor (IGF1R) are controversial. The characterisation of these effects was the aim of the present study.

Methods Short-acting (insulin lispro [B28Lys,B29Pro human insulin], insulin aspart [B28Asp human insulin], insulin glulisine [B3Lys,B29Glu human insulin]) and long-acting (insulin glargine [A21Gly,B31Arg,B32Arg human insulin], insulin detemir [B29Lys( $\varepsilon$-tetradecanoyl),desB30 human insulin]) insulin analogues were studied in three engineered cell models ( $\mathrm{R}^{-}$, IGF1R-deprived mouse fibroblasts transfected with either only human IR-A or IR-B or IGF1R). Receptor binding and phosphorylation, AKT and extracellular signal-regulated kinase (ERK) activation, cell proliferation and colony formation were evaluated after exposing the cells to each analogue and were compared with insulin, IGF1 and the carcinogenic analogue B10Asp.
\end{abstract}

Electronic supplementary material The online version of this article (doi:10.1007/s00125-010-1760-6) contains supplementary material, which is available to authorised users.

L. Sciacca $\cdot$ M. F. Cassarino $\cdot$ M. Genua $\cdot$ G. Pandini •

R. Le Moli $\cdot$ S. Squatrito $\cdot$ R. Vigneri $(\bowtie)$

Endocrinology, Department of Internal and Specialistic Medicine,

University of Catania, Garibaldi-Nesima Hospital,

Via Palermo 636,

95122 Catania, Italy

e-mail: vigneri@unict.it
Results All short-acting insulin analogues produced molecular and biological effects similar but not identical to those of insulin. Relative to insulin, long-acting analogues more strongly activated the ERK pathway via both IR-A and IGF1R as well as increased cell proliferation. At the concentration tested, no analogue (except B10Asp via IR-A) had increased transforming activity.

Conclusions/interpretation Cell models that permit comparisons of the activity of insulin to that of insulin analogues via each receptor individually indicate that only minor differences exist between insulin and short-acting analogues. By contrast, long-acting analogues activate the mitogenic signalling pathway more effectively than insulin and cause increased cell proliferation.

Keywords IGF1R · Insulin analogues · Insulin receptor · Insulin receptor isoforms · Intracellular signalling . Mitogenic effects
Abbreviations
ERK Extracellular signal-regulated kinase
IGF1R Insulin-like growth factor 1 receptor
IR Insulin receptor
$\mathrm{R}^{-}$cells IGF1R-deprived mouse fibroblasts

\section{Introduction}

Insulin has well-documented mitogenic effects in addition to its typical metabolic effects. The mitogenic effects of hyperinsulinaemia may be clinically relevant when considering the large number of individuals with endogenous or exogenous hyperinsulinaemia and the long duration of treatment in diabetic patients $[1,2]$. These concerns also apply to insulin analogues with molecular structures similar 
to that of insulin, which may be used to obtain either faster or more prolonged metabolic effects and improved metabolic control [3, 4]. Insulin analogues may interact differently with receptors for insulin (IR) or IGF1 (IGF1R), activating metabolic and mitogenic pathways in a different way from native insulin [4-9]. Potential risks have been documented for B10Asp, a single amino acid substituted insulin analogue that has increased affinity for both IR and IGF1R as well as longer residence on the IR [10-13]. These biological characteristics are associated with increased mammary tumours in B10Asp-treated female rats [14, 15]. During preclinical and clinical experimentation, all insulin analogues have been tested for their mitogenic potential, but available data are incomplete [16] and sometimes contradictory. For this reason, most analogues are not indicated for treating diabetes during pregnancy.

In addition, it is well known that the insulin receptor may be produced as A or B isoforms with different biological characteristics $[17,18]$. Only minimal data are available on analogue interaction with these isoforms. This information might be important, because the metabolic and/or mitogenic responses of target cells may also depend on the type and proportion of the different receptors they produce [19, 20]. IR-A, for example, is also a high-affinity IGF2 receptor with stronger mitogenic (rather than metabolic) activity than IR-B, which, in contrast, is the typical insulin target tissue receptor and mainly mediates metabolic activity [21].

To investigate the effects of insulin analogues via IR isoforms or IGF1R without the interference of their binding to and activation of the other components of the IR family, we examined the in vitro effects of insulin analogues in an engineered cell model producing only human IR-A, IR-B or IGF1R. In these cells, receptor binding and phosphorylation, AKT and extracellular signal-regulated kinase (ERK) (key signalling proteins for the metabolic and the mitogenic activities of insulin, respectively) activation [22], cell proliferation and colony formation in soft agar were all measured to evaluate the metabolic, mitogenic and transforming potential of each analogue. The study aimed to evaluate the interaction of each analogue with each specific receptor and the consequent signalling activation, as well as the biological response, in comparison with native insulin, IGF1 and the carcinogenic insulin analogue B10Asp.

\section{Methods}

All reagents for cell culture were purchased from Sigma (St Louis, MO, USA). The rapid-acting insulin analogues aspart (B28Asp human insulin) and glulisine (B3Lys, B29Glu human insulin) as well as the long-acting insulin analogue glargine (A21Gly,B31Arg,B32Arg human insulin) were provided by sanofi-aventis (Paris, France), as was the carcinogenic insulin analogue B10Asp [14, 15]. Lispro (B28Lys,B29Pro human insulin) was provided by Eli Lilly (Indianapolis, IN, USA), and the long-acting insulin detemir [B29Lys( $\varepsilon$-tetradecanoyl),desB30 human insulin] was purchased from Novo Nordisk (Bagsvaerd, Denmark). Human insulin and IGF1 were purchased from Calbiochem (Darmstadt, Germany). All ligands were used at $5 \mathrm{nmol} / 1$ except detemir, which contains 3.9 times more insulin per $1 \mathrm{IU}$ than native insulin or other insulin analogues (in terms of biological potency, $0.142 \mathrm{mg}$ detemir is equivalent to $0.036 \mathrm{mg}$ insulin). To better mirror the dose equivalence in clinical use, therefore, detemir was used at $19 \mathrm{nmol} / \mathrm{l}$, a concentration underestimated according to a recent report that indicated that a tenfold higher concentration of detemir is required to achieve a similar maximal biological activity to native insulin in vitro [23].

Biotin was obtained from Calbiochem. Bacto-Agar was from Becton Dickinson (BD Biosciences, Franklin Lakes, NJ, USA). The DELFIA Cell Proliferation kit, ${ }^{125}$ I-labelled insulin and ${ }^{125}$ I-labelled IGF1 were purchased from PerkinElmer (Waltham, MA, USA).

Rabbit polyclonal antibodies recognising either the IR $\beta$ subunit or IGF1R $\beta$-subunit were from Santa Cruz Biotechnology (Santa Cruz, CA, USA); anti-phosphoERK1/2, anti-phospho-AKT, anti-ERK1/2 and anti-AKT antibodies were from Cell Signaling Technology (Danvers, MA, USA); and anti-phosphotyrosine monoclonal antibody 4G10 was from Upstate Biotechnology (Waltham, MA, USA).

\section{Cell models}

$\mathrm{R}^{-}$cells, provided by R. Baserga (Kimmel Cancer Center, Philadelphia, PA, USA), are mouse embryonic fibroblasts derived from animals with a target disruption of the IGFIR gene and therefore do not produce IGF1R. Like NIH 3T3 fibroblasts, $\mathrm{R}^{-}$cells produce endogenous mouse IR at a low level (approximately $5 \times 10^{3}$ receptors/cell) as IR-A isoform [24]. $\mathrm{R}^{-}$cells were stably transfected with the pNTK2 expression vectors containing the cDNAs for either the A $\left(\mathrm{Ex} 11^{-}\right)$or the $\mathrm{B}\left(\mathrm{Ex} 11^{+}\right)$isoforms of human IR or the pECE expression vector containing the human IGF1R cDNA, as previously reported [21].

Receptor expression in each cell type was evaluated by RT-PCR, western blot (see Electronic supplementary material [ESM] Fig. 1a) and specific ELISA [25], which indicated a receptor protein content of $40.5 \mathrm{ng} / 100 \mu \mathrm{g}$ protein in $\mathrm{R}^{-} / \mathrm{IR}-\mathrm{A}$ cells (approximately $1.5 \times 10^{5}$ receptors/ cell), $26.8 \mathrm{ng} / 100 \mu \mathrm{g}$ protein $\left(1.0 \times 10^{5}\right.$ receptors/cell $)$ in $\mathrm{R}^{-} / \mathrm{IR}-\mathrm{B}$ cells and $79 \mathrm{ng} / 100 \mu \mathrm{g}$ protein or $2.4 \times 10^{5}$ receptors/cell in $\mathrm{R}^{+}$cells. Exposure of these cells to the specific ligands, but not to the unrelated ligand EGF, causes receptor and intracellular signalling protein phosphorylation (ESM Fig. 1b). All transfected cells contained high levels 
of the ectopic human receptor (IR-A, IR-B or IGF1R) and low levels $\left(5 \times 10^{3}\right)$ of mouse IR-A. Hypothetically, heterospecific hybrid receptors can be formed (mouse IR-A/ human IR-A, IR-B or IGF1R hemi-receptors), but this was never demonstrated. However, because of the high ratio of transfected human receptors to endogenous mouse IR-A and the reduced affinity of hemi-receptors from different species, the resulting random hybrid receptor formation is likely to be absent or very low.

In these cell types, duplication time in $0.1 \%$ BSA was slow ( $30 \mathrm{~h}$ for $\mathrm{R}^{-} / \mathrm{IR}-\mathrm{A}$ and $\mathrm{R}^{+}$cells and $42 \mathrm{~h}$ for $\mathrm{R}^{-} / \mathrm{IR}-\mathrm{B}$ cells). The proliferation response to hormones was evaluated by Trypan Blue count, and it indicated that cells responded to the ligand of the transfected and expressed receptor (ESM Fig. 1c). No hormone or analogue had a mitogenic effect (evaluated by BrdU incorporation into newly synthesised DNA) on parental, empty vector-transfected $\mathrm{R}^{-}$cells (ESM Fig. 1d).

\section{Binding studies}

Binding studies were carried out in intact cells grown to approximately $80 \%$ confluence, serum starved for 16-18 h and harvested in PBS containing $1 \mathrm{mmol} / \mathrm{l}$ EDTA and $0.1 \%$ BSA. Cells were incubated in the presence of increasing concentrations of either unlabelled insulin, IGF1 or the insulin analogues in red phenol-free minimum essential medium containing $100 \mathrm{mmol} / \mathrm{l}$ HEPES, $0.1 \%$ BSA and $0.06 \mathrm{mg} / \mathrm{ml}$ bacitracin. The tracer $\left(0.2 \mathrm{ng} / \mathrm{ml}{ }^{125} \mathrm{I}\right.$-labelled insulin for $\mathrm{R}^{-} / \mathrm{IR}-\mathrm{A}$ and $\mathrm{R}^{-} / \mathrm{IR}-\mathrm{B}$ cells or $0.1 \mathrm{ng} / \mathrm{ml}$ ${ }^{125}$ I-labelled IGF1 for $\mathrm{R}^{+}$cells) was added for $16 \mathrm{~h}$ at $4{ }^{\circ} \mathrm{C}$, and then cells were washed twice with cold $10 \mathrm{mmol} / \mathrm{l}$ Trisbuffered saline and the cell-associated radioactivity measured. The $\mathrm{EC}_{50}$ was calculated by Scatchard analysis (non-linear regression algorithm in GraphPad Prism 4 software [San Diego, CA, USA]). In the cell models used, neither total nor non-specific binding of insulin was affected by BSA concentrations in the range $0.1-1 \%$.

Receptor autophosphorylation and intracellular substrate (ERK1/2 and AKT) activation

Serum-starved cells were exposed to $5 \mathrm{nmol} / \mathrm{l}$ of insulin, IGF1 or the insulin analogues for the times indicated. Cell lysates were subjected to reducing SDS-PAGE on either $7.5 \%$ (IR and IGF1R) or 10\% (ERK1/2 and AKT) polyacrylamide gels. After electrophoresis, resolved proteins were transferred to nitrocellulose membranes and subjected to immunoblot analysis.

For IR and IGF1R phosphorylation, blots were first probed with anti-phosphotyrosine 4G10 antibody, and then membranes were stripped and reprobed with either anti-IR or anti-IGF1R polyclonal antibodies. For intracellular substrate activation, membranes were immunoblotted with either an anti-phospho-ERK1/2 or an anti-phospho-AKT antibody. The membranes were then stripped and reprobed with the anti-AKT or anti ERK1/2 antibody. Dose-response $(0.05-50 \mathrm{nmol} / \mathrm{l})$ studies were carried out with insulin, glargine and detemir (ESM Fig. 2).

\section{Biological effects}

Proliferation studies The capacity of hormones and analogues to stimulate proliferation was evaluated using a time-resolved fluorometric immunoassay based on BrdU incorporation into newly synthesised DNA. As this reaction is influenced by cell proliferation rate, preliminary tests indicated an appropriate BrdU incubation time of $6 \mathrm{~h}$. Cells were seeded at $1.2 \times 10^{3}$ cells/well for $\mathrm{R}^{-} / \mathrm{IR}-\mathrm{A}$ and $\mathrm{R}^{+}$and at $2.0 \times 10^{3}$ cells/well for $\mathrm{R}^{-} / \mathrm{IR}-\mathrm{B}$ cells that have a lower proliferation rate. Cells starved of serum for $24 \mathrm{~h}$ were exposed for $18 \mathrm{~h}$ to $5 \mathrm{nmol} / 1$ of hormones or analogues (except detemir, at $19 \mathrm{nmol} / \mathrm{l})$. BrdU $(10 \mu \mathrm{mol} / \mathrm{l})$ was added during the last $6 \mathrm{~h}$ of cell exposure to different ligands, and then cells were fixed and DNA denatured. Incorporated BrdU was detected using $0.5 \mu \mathrm{g} / \mathrm{ml}$ europium-labelled monoclonal antibody, and fluorescence activity (proportional to DNA synthesis) was measured by the multilabel counter Wallac 1420 VICTOR3 (Perkin-Elmer).

Anchorage independent growth Transformation potential of hormones and analogues was evaluated by colony formation in semi-solid agar. Briefly, $1 \times 10^{3}$ cells/well were resuspended and seeded in a six-well plate in $0.3 \%$ bactoagar in Dulbecco's modified Eagle's medium (DMEM) with $5 \%$ calf serum and $5 \%$ fetal bovine serum. Wells were pre-coated with $1 \mathrm{ml}$ solid agar $(0.6 \%$ bacto-agar in the same DMEM medium). Hormones or analogues ( $5 \mathrm{nmol} / \mathrm{l}$, except detemir, at $19 \mathrm{nmol} / \mathrm{l}$ ) were added $24 \mathrm{~h}$ after seeding time and then again every $48 \mathrm{~h}$. After 2 weeks, cells were stained with $0.5 \mathrm{mg} / \mathrm{ml} p$-iodonitrotetrazolium, photographed and counted.

\section{Statistical analysis}

Paired, two-tailed Student's $t$ tests with 95\% CI were used to compare the binding affinities $\left(\mathrm{EC}_{50}\right.$ value) and the proliferative effects of analogues with respect to insulin or IGF1. Proliferation data were averaged from 11 separate experiments, each simultaneously evaluating all the ligands under study. Phosphorylated protein densitometric values were determined by averaging three independent experiments, and calculations were performed using a two-way ANOVA test with GraphPad Prism 4 software. Further methods can be found in the ESM. 


\section{Results}

Receptor binding

Insulin bound with high affinity to both IR isoforms but did not bind to IGF1R; IGF1 bound with high affinity to IGF1R, with low affinity to IR-A ( $p<0.01$ vs insulin) and did not bind to IR-B. B10Asp affinity was significantly higher than that of insulin for both IR-A and IR-B and also for IGF1R (Table 1). All short-acting analogues had $\mathrm{EC}_{50}$ values similar to that of insulin for both IR-A and IR-B isoforms. Like insulin, no short-acting analogues bound to IGF1R. Both long-acting analogues had a lower binding affinity for IR-A relative to insulin. Insulin detemir had a much lower affinity than insulin for IR-B. By contrast, both glargine and detemir bound IGF1R with higher affinity than insulin but lower than IGF1 (Table 1).

\section{Receptor phosphorylation}

Receptor phosphorylation induced by insulin, IGF1 and B10Asp reflected their binding affinity. In response to insulin, both IR isoforms were phosphorylated, whereas IGF1R was only weakly phosphorylated (Figs 1, 2 and 3). However, both the magnitude and the kinetics of insulininduced receptor phosphorylation differed, being $25-30 \%$ greater in $\mathrm{R}^{-} / \mathrm{IR}-\mathrm{B}$ cells but more sustained in $\mathrm{R}^{-} / \mathrm{IR}-\mathrm{A}$ cells. The effect of B10Asp on IR-A, IR-B and IGF1R phosphorylation was not different from that elicited by insulin (Figs 1, 2 and 3). By contrast, IGF1 actively phosphorylated IGF1R but had no significant effect on IRA and IR-B.

All three short-acting analogues caused IR-A phosphorylation similar to insulin in terms of magnitude and activation pattern (Fig. 1), whereas they caused shorterlasting IR-B phosphorylation than insulin, although the differences were not statistically significant (Fig. 2). These analogues had a similar effect on IGF1R phosphorylation to that of insulin (Fig. 3). Glargine and detemir had an effect on IR-A and IR-B phosphorylation similar to that elicited by insulin (Figs 1 and 2), but they differed in IGF1R phosphorylation: glargine was similar to insulin, whereas detemir induced a significantly $(p<0.01)$ more marked effect (Fig. 3).

Intracellular signalling: AKT and ERK phosphorylation

After exposure to insulin, ERK activation kinetics diverged from AKT activation kinetics in the different cell lines. In IR-A expressing cells (Fig. 4), ERK activation increased in a time-dependent manner, whereas AKT activation peaked early and decreased by $10 \mathrm{~min}$. Therefore, the ERK:AKT activation ratio increased with time, with a progressive ERK predominance (Fig. 4). By contrast, in IR-B-expressing cells and in $\mathrm{R}^{+}$cells, insulin-induced AKT and ERK phosphorylation followed a similar time-activation pattern (Figs 5 and 6). In all cell types, B10Asp activated AKT in a similar way to insulin (Figs 4, 5 and 6), but it was significantly more effective than insulin at activating ERK in $\mathrm{R}^{-} / \mathrm{IR}-\mathrm{A}$ and $\mathrm{R}^{+}$cells (Figs 4,5 and 6 ). In $\mathrm{R}^{+}$cells, B10Asp paralleled the effects of IGF1 (Fig. 6).

Short-acting analogues had a similar but more persistent effect compared with insulin on AKT phosphorylation in $\mathrm{R}^{-} / \mathrm{IR}-\mathrm{A}$ cells $(p<0.05$ at $10 \mathrm{~min}$ for all short-acting analogues) (Fig. 4). In these cells, the activation of ERK by short-acting analogues was not significantly different from insulin, although the time profile of aspart and lispro appeared different from that of glulisine (Fig. 4).

In $\mathrm{R}^{-} / \mathrm{IR}-\mathrm{B}$ cells, lispro and glulisine but not aspart phosphorylated AKT less than insulin did $(p<0.05$ for both analogues) (Fig. 5). In these cells, all short-acting analogues had a delayed effect relative to insulin on ERK phosphorylation, and this was significantly reduced for glulisine $(p<0.01)$ and lispro $(p<0.05)$ (Fig. 5). All short-acting analogues, like insulin, had only a minimal effect on AKT and ERK in IGF1R-producing $\mathrm{R}^{+}$cells (Fig. 6).

Table 1 Insulin, IGF1 and insulin analogue binding affinity for the two IR isoforms and IGF1R

\begin{tabular}{|c|c|c|c|c|c|c|c|c|}
\hline \multirow[t]{2}{*}{ Receptor types } & \multicolumn{8}{|c|}{$\mathrm{EC}_{50}$ of unlabelled ligand $(\mathrm{nmol} / \mathrm{l})$} \\
\hline & Insulin & IGF1 & B10Asp & Aspart & Lispro & Glulisine & Glargine & Detemir \\
\hline $\mathrm{R}^{-} / \mathrm{IR}-\mathrm{A}$ & $0.40 \pm 0.10$ & $68.1 \pm 6.10^{\mathrm{b}}$ & $0.27 \pm 0.10^{\mathrm{a}}$ & $0.60 \pm 0.15$ & $0.43 \pm 0.15$ & $0.61 \pm 0.03$ & $0.93 \pm 0.17^{\mathrm{a}}$ & $0.90 \pm 0.26^{\mathrm{a}}$ \\
\hline $\mathrm{R}^{-} / \mathrm{IR}-\mathrm{B}$ & $0.49 \pm 0.05$ & $>100$ & $0.20 \pm 0.01^{\mathrm{a}}$ & $0.70 \pm 0.25$ & $0.54 \pm 0.11$ & $0.74 \pm 0.25$ & $0.58 \pm 0.31$ & $14.01 \pm 1.83^{\mathrm{b}}$ \\
\hline $\mathrm{R}^{+}(\mathrm{IGF} 1 \mathrm{R})$ & $>1,000$ & $2.23 \pm 0.23$ & $\sim 400$ & $>1,000$ & $>1,000$ & $>1,000$ & $\sim 300$ & $\sim 300$ \\
\hline
\end{tabular}

Data represent the mean $\pm \mathrm{SD}$ of three independent experiments

$\mathrm{R}^{-}$-derived cells were treated as indicated in the Methods. Cell-associated radioactivity was measured using a $\gamma$-counter

a $p<0.05$ (Student's $t$ test for paired value with respect to insulin)

${ }^{\mathrm{b}} p<0.01$ (Student's $t$ test for paired value with respect to insulin) 
a
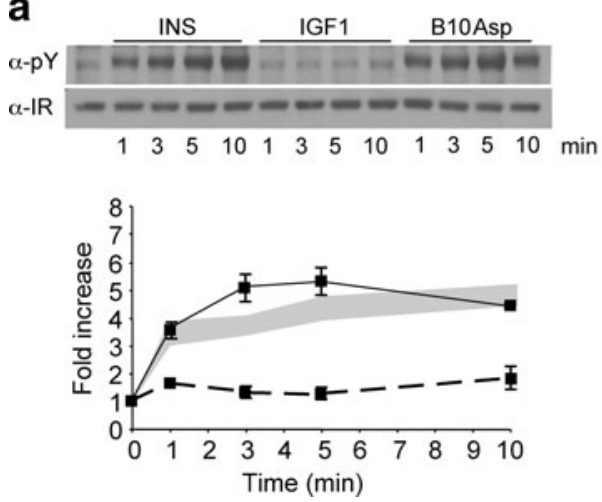

b
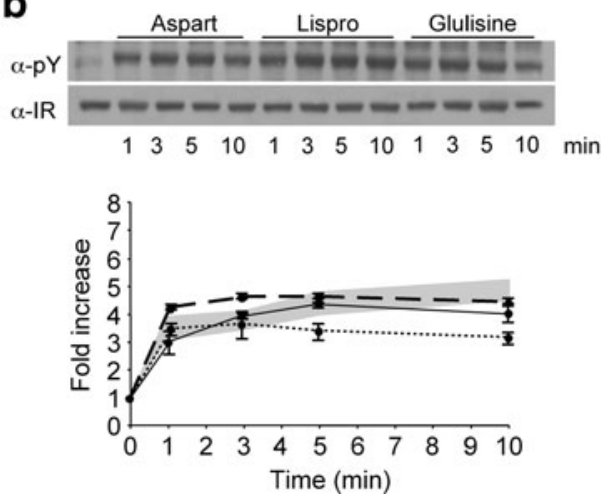

C
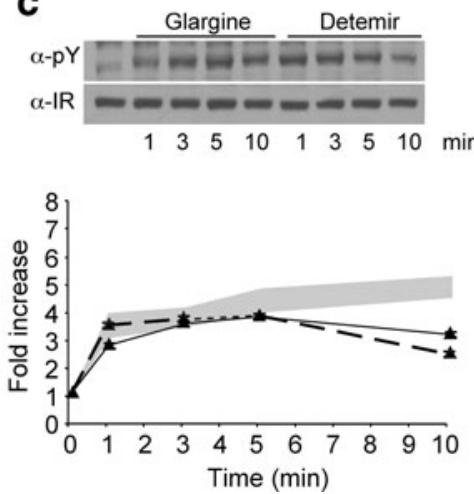

Fig. 1 Receptor phosphorylation in $\mathrm{R}^{-} / \mathrm{IR}-\mathrm{A}$ cells. Serum-starved $\mathrm{R}^{-} /$ IR-A cells were incubated with or without $5 \mathrm{nmol} / 1$ of insulin, IGF1 or B10Asp (a), short-acting analogues (b) or long-acting analogues (c) for the indicated times. Insulin detemir was used at $19 \mathrm{nmol} / \mathrm{l}$, as indicated in the Methods. Cell lysates were separated by SDS-PAGE and immunoblotted with 4G10 phosphotyrosine antibody. Membranes were stripped and reprobed with IR $\beta$-specific antibody to control for

Glargine and detemir activated AKT similarly to insulin in IR-A- and IGF1R-producing cells (Figs 4 and 6) but significantly less than insulin in IR-B-producing cells $(p<0.001$ for both) (Fig. 5). By contrast, ERK phosphorylation induced by glargine and detemir was significantly higher than insulin at 3 and 5 min in $\mathrm{R}^{-} / \mathrm{IR}-\mathrm{A}$ cells $(p<0.05$ for glargine and $p<0.01$ for detemir) (Fig. 4) but was similar to insulin in $\mathrm{R}^{-}$/IR-B cells (Fig. 5). Therefore, both long-acting analogues caused an ERK:AKT activation ratio clearly shifted in favour of ERK in all cell models. In IGF1Rexpressing cells, their effect was similar to that of IGF1 and higher than that of insulin ( $p<0.001$ for both) (Fig. 6).

These observations were confirmed in dose-response experiments where, in IR-A- and IGF1R-producing cells, both glargine and detemir phosphorylated ERK more than protein loading. Blots (upper panel) are representative of three independent experiments. Densitometric average values $( \pm \mathrm{SD})$ (lower panel) are expressed as fold increase over basal activation. Insulin mean value \pm SD is indicated by the grey area. a Solid line, B10Asp; dashed line, IGF1; b short-acting analogues: solid line, aspart; dashed line, lispro; dotted line, glulisine; c long-acting analogues: solid line, glargine; dashed line, detemir

insulin at all concentrations, including the lowest tested (0.05 nmol/l) (ESM Fig. 2).

\section{Cell proliferation}

Insulin induced significant proliferation in both IR-A- and IR-B-producing cells ( $p<0.001$ and $p<0.0001$, respectively), whereas it was ineffective in $\mathrm{R}^{+}$cells (Fig. 7). By contrast, IGF1 induced proliferation in $\mathrm{R}^{+}$cells but had no effect in $\mathrm{R}^{-} /$IR-A and $\mathrm{R}^{-} /$IR-B cells (Fig. 7).

Short-acting analogues had a proliferative effect similar to insulin in $\mathrm{R}^{-} /$IR-A and $\mathrm{R}^{-} / \mathrm{IR}-\mathrm{B}$ cells (Fig. 7). In IGF1Rproducing cells, lispro and aspart were similar to insulin, whereas glulisine induced more proliferation than insulin $(p<0.05)$ (Fig. 7). a
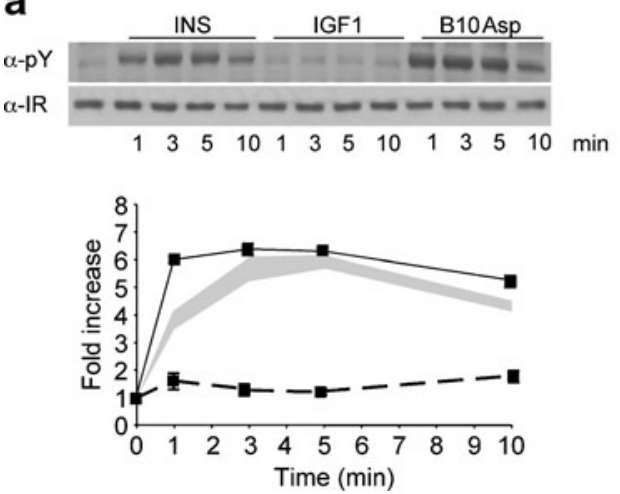

Fig. 2 Receptor phosphorylation in $\mathrm{R}^{-} / \mathrm{IR}-\mathrm{B}$ cells. Receptor phosphorylation was evaluated in $\mathrm{R}^{-} / \mathrm{IR}-\mathrm{B}$ cells. Data are shown as indicated in Fig. 1. Average densitometric values $( \pm \mathrm{SD})$ of three separate experiments are shown as fold increase over basal activity.
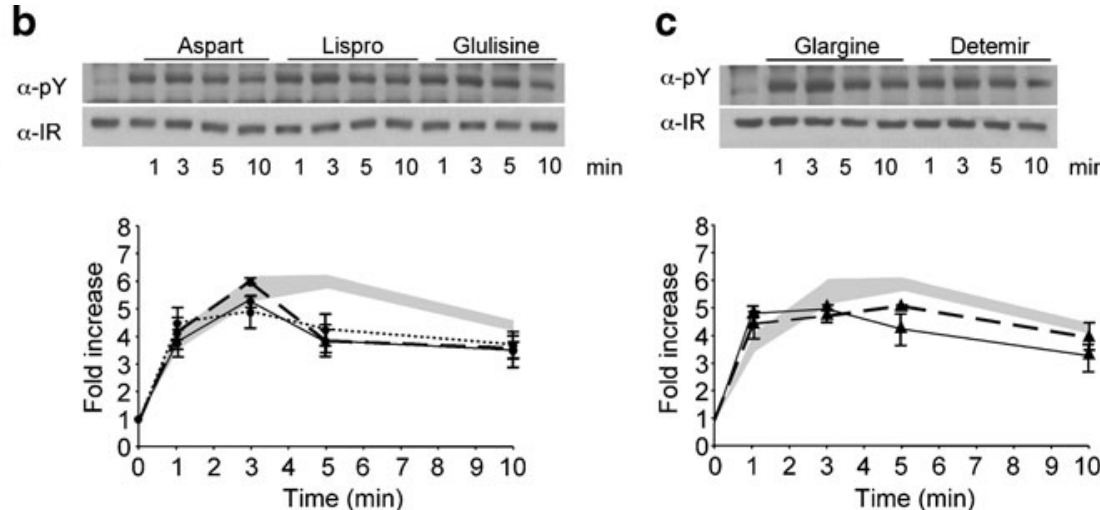

Insulin (mean $\pm \mathrm{SD}$ ) is indicated with a grey area. a Solid line, B10Asp; dashed line, IGF1; b short-acting analogues: solid line, aspart; dashed line, lispro; dotted line, glulisine; c long-acting analogues: solid line, glargine; dashed line, detemir 
a

$\alpha-\mathrm{pY}$ INS IGF1 B10Asp $\alpha-$ IGF1R

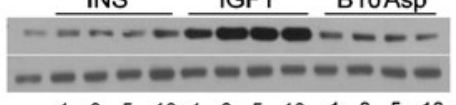

$\begin{array}{lllllllllllll}1 & 3 & 5 & 10 & 1 & 3 & 5 & 10 & 1 & 3 & 5 & 10 & \mathrm{~min}\end{array}$

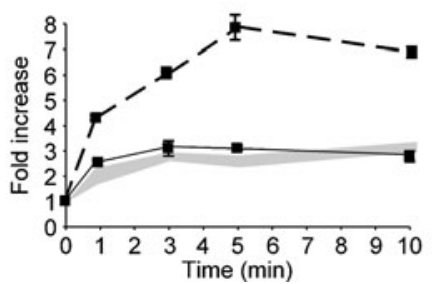

b

$\alpha-p Y$ $\alpha-I G F 1 R$

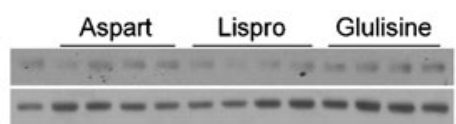

$\begin{array}{lllllllllllll}1 & 3 & 5 & 10 & 1 & 3 & 5 & 10 & 1 & 3 & 5 & 10 & \mathrm{~min}\end{array}$

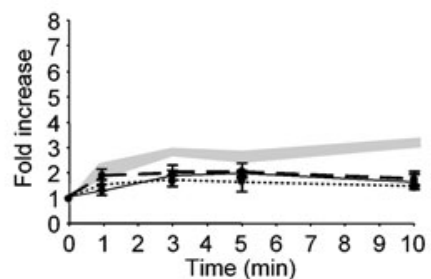

C

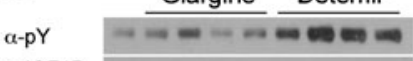
$\alpha-I G F 1 R$

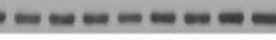

$\begin{array}{lllllllll}1 & 3 & 5 & 10 & 1 & 3 & 5 & 10 & \mathrm{~min}\end{array}$

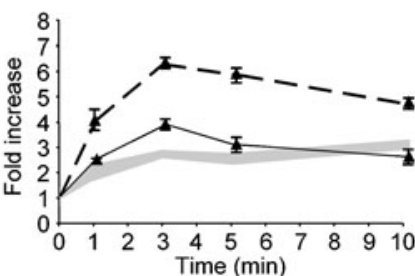

Fig. 3 Receptor phosphorylation in $\mathrm{R}^{+}$cells. Receptor phosphorylation was evaluated in IGF1R-expressing cells. Data are shown as indicated in Fig. 1. Densitometric average values $( \pm \mathrm{SD})$ of three independent experiments of IGF1R phosphorylation are shown. Data are expressed

Both glargine and detemir induced a greater proliferative effect than insulin in $\mathrm{R}^{-} / \mathrm{IR}-\mathrm{A}, \mathrm{R}^{-} / \mathrm{IR}-\mathrm{B}$ and $\mathrm{R}^{+}$cells (Fig. 7). The differences were statistically significant for detemir in $\mathrm{R}^{-}$/IR-A and $\mathrm{R}^{+}$cells as well as for glargine in $\mathrm{R}^{-} / \mathrm{IR}-\mathrm{B}$ and $\mathrm{R}^{+}$cells (Fig. 7). as fold increase over basal activity. Insulin mean value \pm SD is indicated with a grey area. a Solid line, B10Asp; dashed line, IGF1; b short-acting analogues: solid line, aspart; dashed line, lispro; dotted line, glulisine; c long-acting analogues: solid line, glargine; dashed line, detemir

Anchorage-independent cell growth

Without hormone stimulation, anchorage-independent colony formation ( $>250 \mu \mathrm{m}$ diameter) occurred spontaneously at a low rate in the three cell types (Table 2). Insulin stimulated a

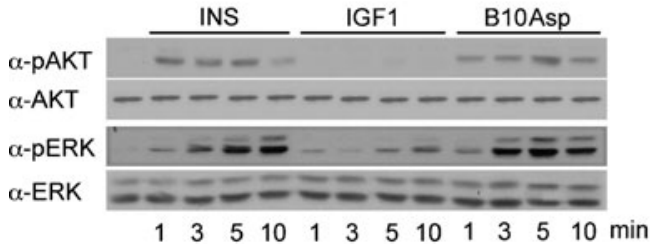

d

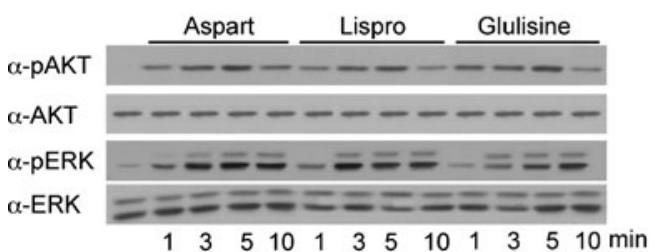

g

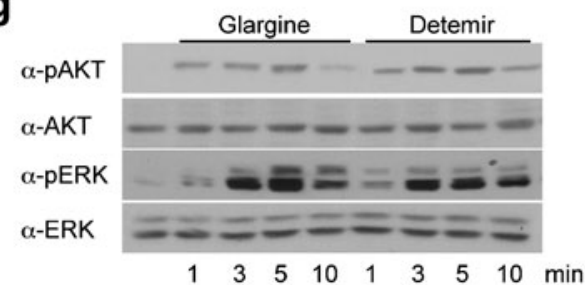

$\mathbf{b}_{8}$

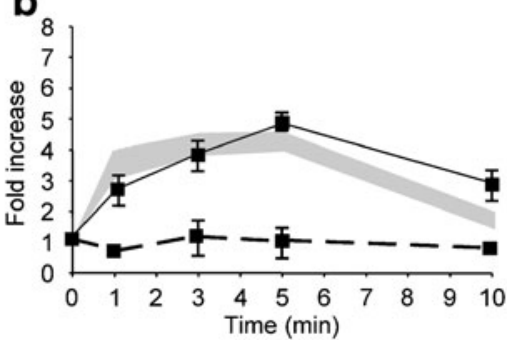

e

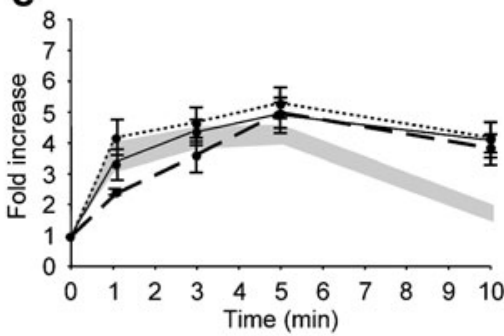

h

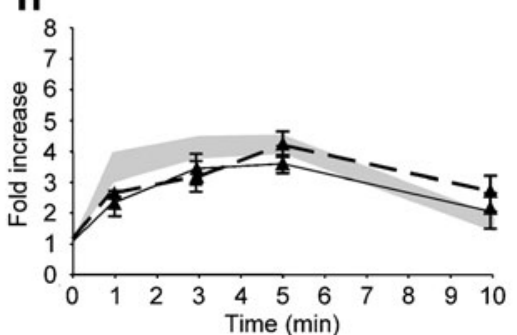

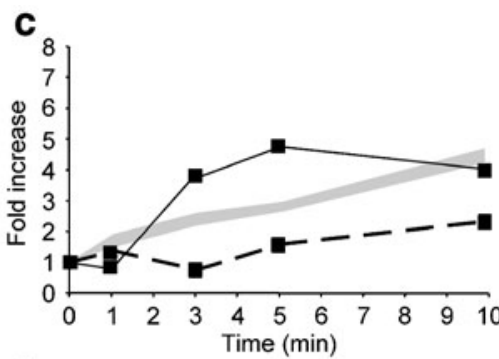

f

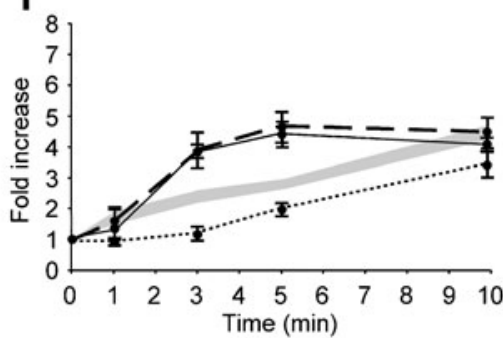

i

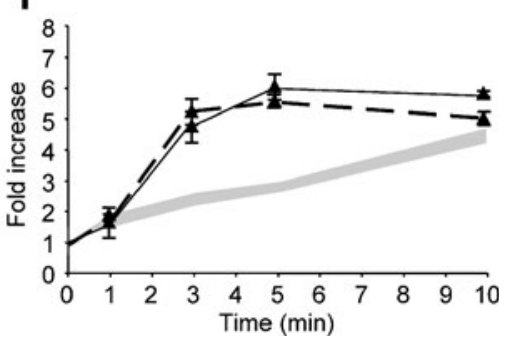

Fig. 4 Intracellular signalling in $\mathrm{R}^{-} / \mathrm{IR}-\mathrm{A}$ cells. Serum-starved $\mathrm{R}^{-} / \mathrm{IR}-\mathrm{A}$ cells were incubated with or without $5 \mathrm{nmol} / 1$ of either insulin, IGF1 or B10Asp (a, b, c), short-acting analogues (d, e, f) or long-acting analogues $(\mathbf{g}, \mathbf{h}, \mathbf{i})$ for the indicated times. Detemir was used at $19 \mathrm{nmol} / \mathrm{l}$. Cell lysates were separated by SDS-PAGE and immunoblotted with a specific antibody against either phospho-AKT or phosphoERK. Membranes were then stripped and reprobed with a total AKT- or a total ERK-specific antibody to control for protein loading. Single western blots are representative of three independent experiments (left). Densitometric average values $( \pm \mathrm{SD})$ of AKT (middle) or ERK (right) phosphorylation are shown. Data are expressed as fold increase over basal activity. Insulin mean value $\pm \mathrm{SD}$ is indicated with a grey area. b, c Solid line, B10Asp; dashed line, IGF1; e, f solid line, aspart; dashed line, lispro; dotted line, glulisine; h, i solid line, glargine; dashed line, detemir 
a

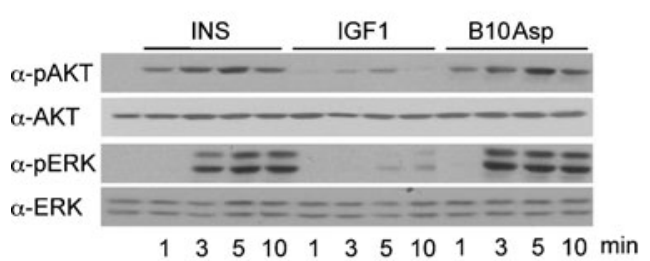

d

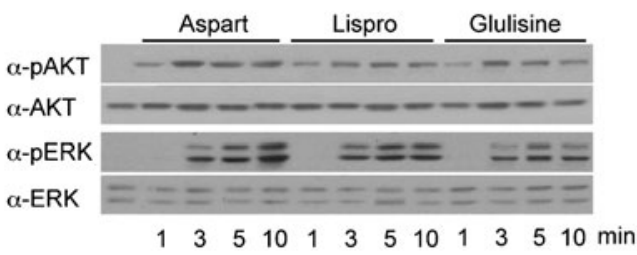

g

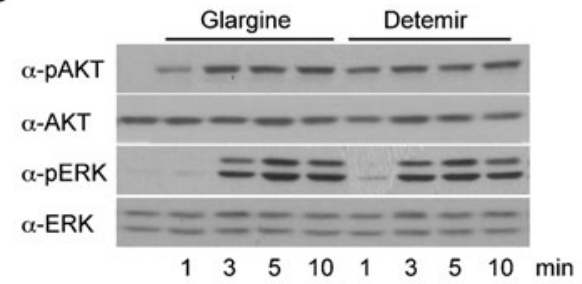

b

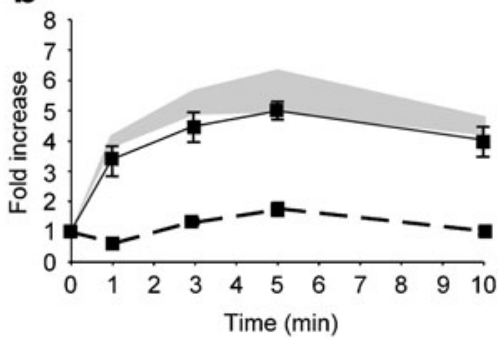

e

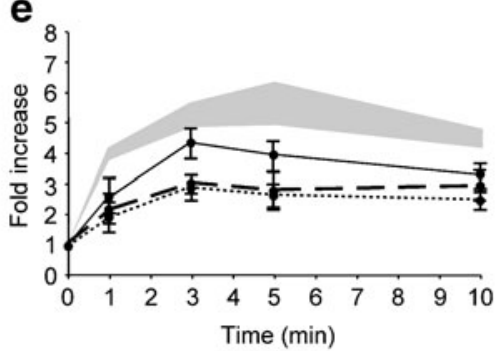

h

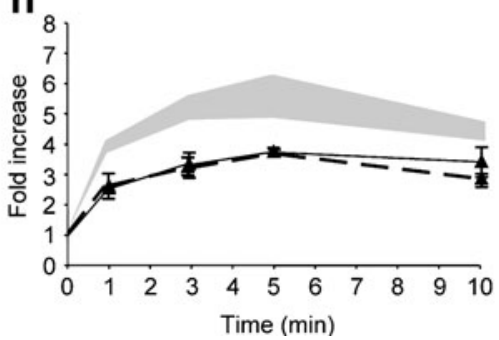

C

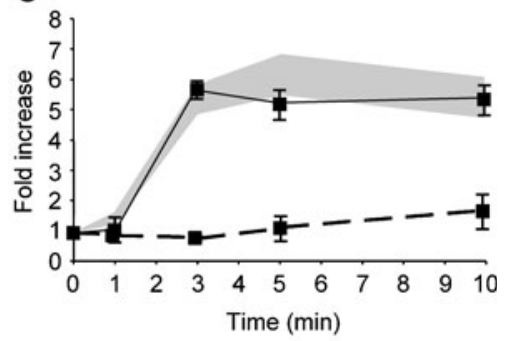

f

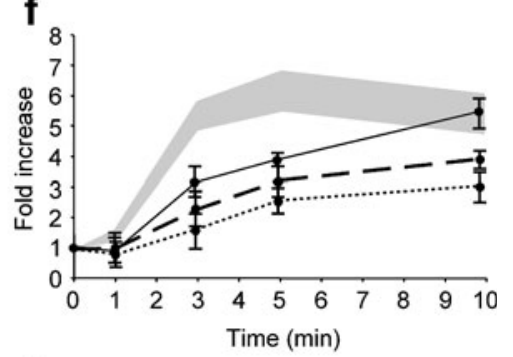

i

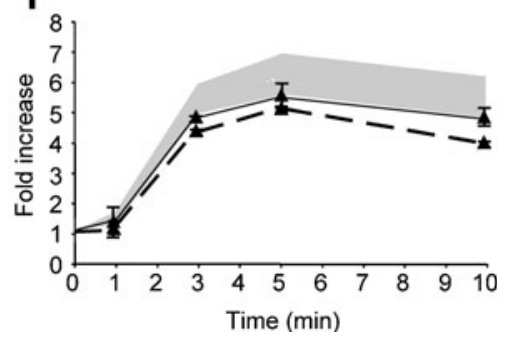

Fig. 5 Intracellular signalling in $\mathrm{R}^{-} / \mathrm{IR}-\mathrm{B}$ cells. Both AKT and ERK phosphorylation were evaluated in $\mathrm{R}^{-} / \mathrm{IR}-\mathrm{B}$ cells. Data are shown as specified in Fig. 4. Average densitometric values $( \pm \mathrm{SD})$ of three separate experiments are shown as fold increase over basal activation.
Insulin (mean $\pm \mathrm{SD}$ ) is indicated with a grey area. b, c Solid line, B10Asp; dashed line, IGF1; e, f solid line, aspart; dashed line, lispro; dotted line, glulisine; h, i solid line, glargine; dashed line, detemir colony formation in both $\mathrm{R}^{-} / \mathrm{IR}-\mathrm{A}$ and $\mathrm{R}^{-} / \mathrm{IR}-\mathrm{B}$ cells and to a lesser degree in $\mathrm{R}^{+}$cells, in which IGF1 was tenfold more effective. IGF1 was similar to insulin in $\mathrm{R}^{-} / \mathrm{IR}-\mathrm{A}$ cells and without effect in $\mathrm{R}^{-} / \mathrm{IR}-\mathrm{B}$ cells. At the concentration tested, no insulin analogue had an increased capacity for promoting anchorage-independent cell growth with respect to insulin except B10Asp, which was twofold more effective than insulin in $\mathrm{R}^{-} / \mathrm{IR}-\mathrm{A}$ cells (Table 2). Further results can be found in the ESM.

\section{Discussion}

Insulin is a growth factor, both in vitro and in vivo. Its mitogenic effect was first believed to occur only at high concentrations via IGF1R, but later it was demonstrated to occur also at lower concentrations via its own receptor [26]. The mitogenic effect of insulin is influenced by the relative abundance of receptor expression in target cells [19, 20,27] and also by IR isoform prevalence [21, 28, 29].

Today, insulin analogues are used in millions of diabetic patients, although the effects of these analogues at the molecular and biological levels are not well defined. Numerous studies have tested the biological characteristics of insulin analogues in comparison to insulin in a variety of cell models, mostly in cancer cells [13, 19, 20,30-32] and/ or with high doses of the ligands examined (up to two or three orders of magnitude greater than levels reached in clinical use) [19, 27, 32-34]. Moreover, the investigated models have been very heterogeneous. In the study of Kurtzhals et al. [13], for instance, receptor binding was measured with solubilised semi-purified human IR-A, insulin receptor dissociation was measured in transfected Chinese hamster ovary (CHO) cells overproducing IR (not indicated whether IR-A or IR-B), metabolic effects were studied in mouse adipocytes (mouse IR), and mitogenic potency was evaluated in a human osteosarcoma cell line producing very little IR (fewer than 1,000 per cell) and high IGF1R (30,000 per cell). Interestingly, in that study, detemir, known to be interfered with by albumin, was studied in the absence of albumin for binding affinity and in the presence of $1.0 \%$ human albumin for metabolic potency and $0.5 \%$ BSA for mitogenic potency. Results were then corrected for the assumed free detemir level [13]. 
a

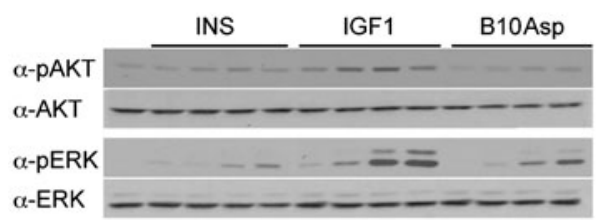

$\begin{array}{lllllllllllll}1 & 3 & 5 & 10 & 1 & 3 & 5 & 10 & 1 & 3 & 5 & 10 & \mathrm{~min}\end{array}$

d

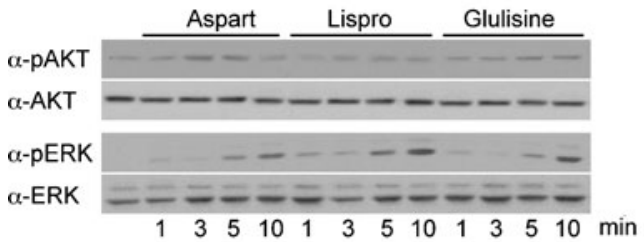

g

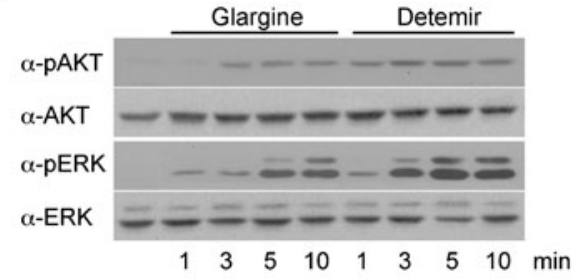

b

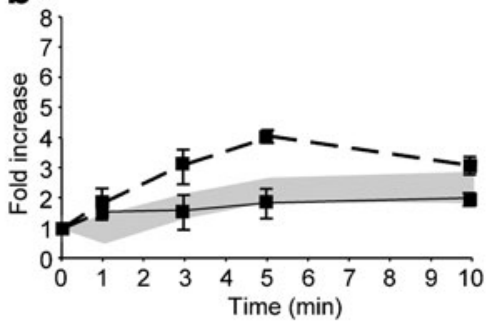

e

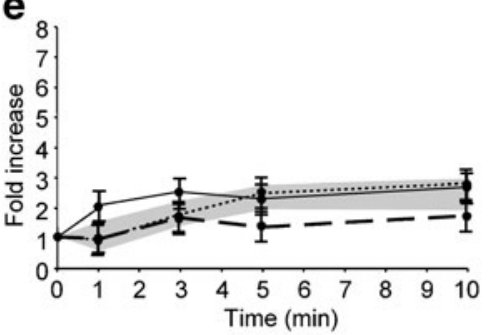

h

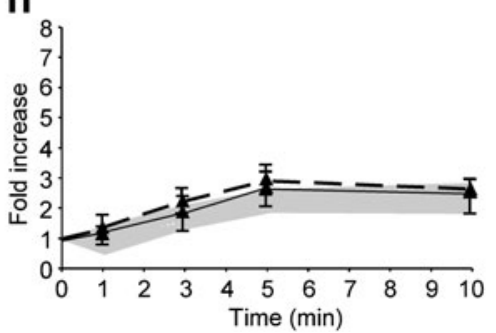

C

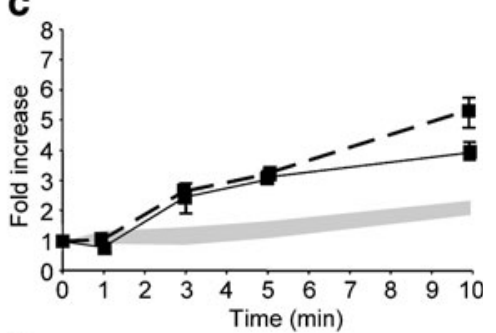

f

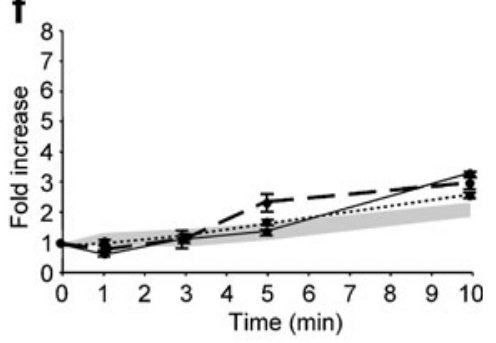

i

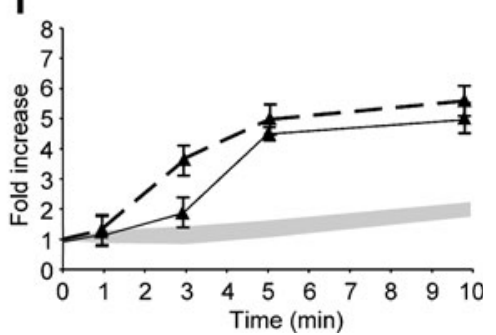

Fig. 6 Intracellular signalling in $\mathrm{R}^{+}$cells. Intracellular signalling was evaluated in $\mathrm{R}^{+}$cells stimulated with insulin, IGF1 or B10Asp (a, b, c), short-acting analogues (d, e, f) or long-acting analogues $(\mathbf{g}, \mathbf{h}, \mathbf{i})$. Data are shown as indicated in Fig. 4. Average densitometric values
$( \pm \mathrm{SD})$ of three separate experiments are shown as fold increase over basal activity. Insulin (mean $\pm \mathrm{SD}$ ) is indicated with a grey area. b, c Solid line, B10Asp; dashed line, IGF1; e, f solid line, aspart; dashed line, lispro; dotted line, glulisine; h, i solid line, glargine; dashed line, detemir
As a consequence of the different models studied, the variability of experimental procedures and the comparison in each study of some, but not all, insulin analogues, conclusions have been controversial and the molecular differences between analogue signalling poorly defined. In the present study, we compared with insulin and IGF1 all insulin analogues in three non-transformed cell models derived from the same parental cell and producing only the human IR-A, IR-B or IGF1R. These receptors represent a predominantly metabolic receptor (IR-B), an intermediate metabolic/ mitogenic receptor (IR-A) and a predominantly mitogenic receptor (IGF1R). In cells producing only one of these receptors, insulin and IGF1 caused the molecular and biological effects expected on the basis of present knowledge
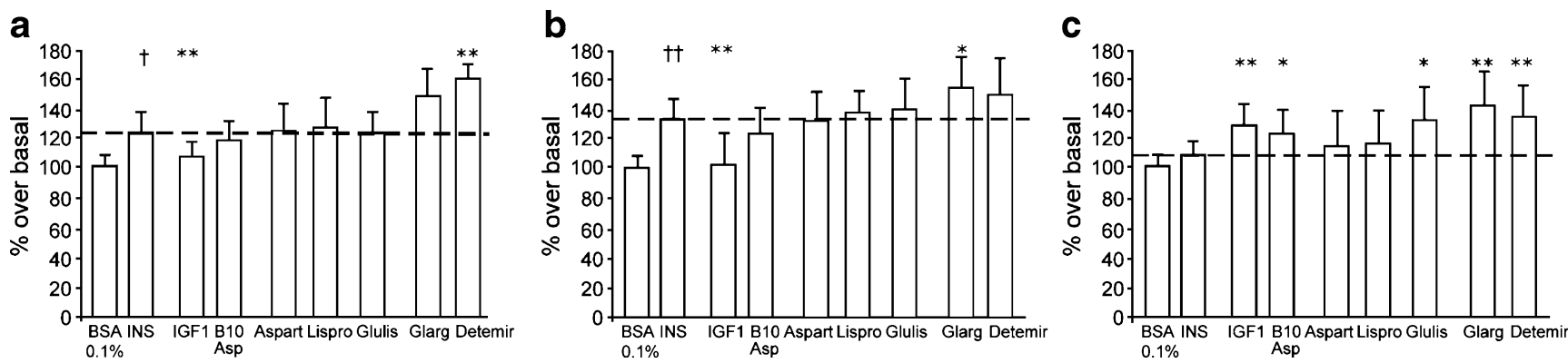

Fig. 7 Cell growth. Cell DNA was measured in serum-starved $\mathrm{R}^{-} / \mathrm{IR}-$ A (a), $\mathrm{R}^{-} / \mathrm{IR}-\mathrm{B}$ (b) and $\mathrm{R}^{+}$cells (c) exposed for $18 \mathrm{~h}$ to insulin, IGF1 or insulin analogues at $5 \mathrm{nmol} / 1$ (except detemir, at $19 \mathrm{nmol} / \mathrm{l}$ ). BrdU was added to the culture medium for $6 \mathrm{~h}$, and new DNA synthesis was evaluated by europium-labelled anti-BrdU antibody. Each column indicates the mean value of 11 independent experiments as the percentage increase with respect to unstimulated cells (BSA $0.1 \%$, white bars). SD values are indicated for each column. The broken line indicates the level of the insulin effect. Student's $t$ test, for paired value: insulin effect vs unstimulated ${ }^{\dagger} p<0.001,{ }^{\dagger \dagger} p<0.0001$; IGF1 and analogue effects vs insulin $* p<0.05, * * p<0.01$ 
Table 2 Anchorage-independent cell growth stimulated by $5 \mathrm{nmol} / \mathrm{l}$ insulin, IGF1 or insulin analogues ${ }^{\mathrm{a}}$

\begin{tabular}{|c|c|c|c|c|c|c|c|c|c|}
\hline \multirow[t]{2}{*}{ Receptor types } & \multicolumn{9}{|c|}{ Number of colonies } \\
\hline & Basal & Insulin & IGF1 & B10Asp & Aspart & Lispro & Glulisine & Glargine & Detemir \\
\hline $\mathrm{R}^{-} / \mathrm{IR}-\mathrm{A}$ & $23 \pm 7$ & $65 \pm 8$ & $58 \pm 10$ & $112 \pm 38^{\mathrm{b}, \mathrm{c}}$ & $87 \pm 20$ & $73 \pm 11$ & $67 \pm 11$ & $63 \pm 13$ & $83 \pm 20$ \\
\hline $\mathrm{R}^{-} / \mathrm{IR}-\mathrm{B}$ & $2 \pm 2$ & $36 \pm 1$ & $3 \pm 1$ & $36 \pm 8$ & $36 \pm 10$ & $32 \pm 9$ & $34 \pm 9$ & $27 \pm 9$ & $34 \pm 4$ \\
\hline $\mathrm{R}^{+}(\mathrm{IGF} 1 \mathrm{R})$ & $7 \pm 2$ & $11 \pm 1$ & $56 \pm 18$ & $13 \pm 6$ & $7 \pm 3$ & $10 \pm 1$ & $9 \pm 3$ & $10 \pm 3$ & $10 \pm 1$ \\
\hline
\end{tabular}

Data represent the mean $\pm \mathrm{SD}$ of three independent experiments

Cells were treated as indicated in the Methods. Colonies were counted by Gel Documentation (GeneQuant software; Bio-Rad Laboratories, Hercules, CA, USA), setting colony diameter greater than $250 \mu \mathrm{m}$

${ }^{a}$ Insulin detemir was used at $19 \mathrm{nmol} / \mathrm{l}$ (see Methods)

${ }^{\mathrm{b}} p<0.05$ (Student's $t$ test for paired value with respect to insulin)

${ }^{\mathrm{c}} p<0.05$ (Student's $t$ test for paired value with respect to IGF1)

[18]. These models, therefore, have the unique property of enabling comparisons of the molecular and biological effects stimulated by insulin or its analogues via one receptor type, avoiding the interference of the other cognate receptors and providing comparable data for short-acting and long-acting insulin analogues in the same, nonmalignantly transformed system.

Our experimental models and procedures, however, have some limitations. First, the genetic background of the cells does not reflect normal human cells, which usually express all of the three studied receptors (and the derived hybrid receptors). Second, receptors in engineered cells are overproduced in comparison with most normal human cell types, possibly influencing biological responsiveness. Finally, the ligand concentration used was approximately one order of magnitude higher than levels reached in clinical use, although it was lower than in most published studies.

Short-acting analogues behave in a way similar, but not identical, to insulin. Although binding affinities to the three receptors were similar to that of insulin in $\mathrm{R}^{-} / \mathrm{IR}-\mathrm{B}$ cells, receptor phosphorylation was shorter, and AKT and ERK phosphorylation was reduced in comparison with insulin. By contrast, in $\mathrm{R}^{-} / \mathrm{IR}-\mathrm{A}$ cells, short-acting analogues induced a more prolonged AKT activation, whereas aspart and lispro, but not glulisine, had a more rapid effect on ERK activation than insulin. Maximum stimulation of intracellular signals for short-acting analogues, however, was not different from insulin. The short-acting analogues had effects similar to insulin on IGF1R-producing cells. Finally, these analogues had a mitogenic potency similar to insulin; except glulisine, which stimulated IGF1Rproducing cell proliferation more than insulin. These results confirm most previous data obtained in other cell models and are reassuring in terms of the mitogenic effect of these analogues. However, the long-term consequences of the small differences in molecular activation between insulin and short-acting analogues remain unknown.
At variance with short-acting analogues, long-acting analogues had marked differences relative to insulin. Both analogues had reduced affinities for IR-A, while affinity for IR-B was reduced only for detemir, as already reported $[13,35]$, and the affinities of both for IGF1R were higher than insulin.

In all cell models, long-acting analogues induced a predominant ERK activation: the ERK:AKT phosphorylation ratio was clearly increased, as was cell proliferation in comparison with insulin. In cancer cells long-acting analogues have been shown to have an increased proliferative effect relative to insulin $[13,19,20,32]$. Our studies confirm these observations and clearly indicate that this effect of longacting analogues does not occur only via IGF1R [20,32, 34] but also via the IRs, especially IR-A. Moreover, at variance with previous studies in non-transformed cells [7, 23, 33, 36] our study indicates that, when compared with insulin and its short-acting analogues, long-acting analogues caused increased cell proliferation also in the three non-transformed cell types examined. It must be considered, however, that our cell models overexpressed the transfected receptor and their response may reflect data recently reported in cultured cancer cells, which often overproduce IGF1R and IR and specifically IR-A [18].

Our data indicate that similar effects are produced by glargine and detemir, an observation that is at variance with some previous reports suggesting a weaker effect of detemir on IGF1R binding and activation and on proliferation stimulation [13, 20, 23, 32]. Comparative studies with detemir are difficult because of its reduced metabolic effect (and the consequent increased equivalent dose used in clinical practice), a likely consequence of its high binding affinity for albumin. When metabolic or mitogenic effects are studied in the presence of albumin concentrations higher than $0.1 \%$ (like many previous studies), the number of bioactive detemir molecules that can access the receptor and activate biological signals is greatly reduced and 
probably variable, depending on the experimental conditions. We believe this is the reason for most discrepancies between the present and previous studies.

Finally, no insulin analogue, except B10Asp, caused greater anchorage-independent cell growth (a transformation marker) than insulin itself. Interestingly, at the concentration tested, B10Asp produced this effect only in cells producing the $\mathrm{A}$ isoform of IR.

In conclusion, in each of the three in vitro models that we used, each producing only one receptor type, the long-acting analogues had a significantly increased mitogenic activity with respect to insulin and short-acting analogues. This biological effect was consistent with the molecular activation of receptors and intracellular signalling substrates. Our in vitro observations do not necessarily mimic what happens when the analogues are used in patients, because different conditions are present in vivo. For instance, glargine insulin is metabolised to $M_{1}$ and $M_{2}$ derivatives [37], and detemir is bound by albumin at concentrations higher than that used in our studies. Moreover, different tissues will respond differently on the basis of the quantity and the quality of the receptors produced. Therefore, the question of whether insulin analogues, and specifically long-acting analogues, have increased mitogenic potency in patients is not answered by this study. Randomised, prospective clinical studies on this issue are recognised to be difficult because of the heterogeneity of the diabetic population and the number of confounding factors associated with the disease, which are very difficult to correct for in retrospective observational studies and to normalise in prospective ones. Therefore, the concerns regarding the clinical risk in patients treated with the long-acting insulin analogues with increased mitogenic effect are unlikely to be unravelled by epidemiological studies in the near future $[16,38]$. The disproportionately increased mitogenic effects observed in vitro provide the biological basis for better directing clinical as well as pharmacological research and confirm the need for careful follow-up of patients treated with the long-term insulin analogues.

Acknowledgements These studies were supported by an unconditional grant from sanofi-aventis (Paris, France) and by funds from the University of Catania to R. Vigneri.

Duality of interest The authors declare that these studies were partially supported by an unconditional grant from sanofi-aventis (Paris, France), which produces glulisine and glargine insulin analogues. There is no other duality of interest associated with this manuscript.

\section{References}

1. Vigneri P, Frasca F, Sciacca L, Frittitta L, Vigneri R (2006) Obesity and cancer. Nutr Metab Cardiovasc Dis 16:1-7
2. Vigneri P, Frasca F, Sciacca L, Pandini G, Vigneri R (2009) Diabetes and cancer. Endocr Relat Cancer 16:1103-1123

3. Hirsch IB (2005) Insulin analogues. N Engl J Med 352:174-183

4. Vajo Z, Fawcett J, Duckworth WC (2001) Recombinant DNA technology in the treatment of diabetes: insulin analogs. Endocr Rev 22:706-717

5. Drejer K (1992) The bioactivity of insulin analogues from in vitro receptor binding to in vivo glucose uptake. Diab Metab Rev 8:259-285

6. Slieker LJ, Brooke GS, DiMarchi RD et al (1997) Modifications in the B10 and B26-30 regions of the B chain of human insulin alter affinity for the human IGF-I receptor more than for the insulin receptor. Diabetologia 40(Suppl 2):S54-S61

7. Ciaraldi TP, Carter L, Seipke G, Mudaliar S, Henry RR (2001) Effects of the long-acting insulin analog insulin glargine on cultured human skeletal muscle cells: comparisons to insulin and IGF-I. J Clin Endocrinol Metab 86:5838-5847

8. Rakatzi I, Ramrath S, Ledwig D et al (2003) A novel insulin analog with unique properties: LysB3, GluB29 insulin induces prominent activation of insulin receptor substrate 2, but marginal phosphorylation of insulin receptor substrate 1. Diabetes 52:2227-2238

9. Jensen M, De Meyts P (2009) Molecular mechanisms of differential intracellular signaling from the insulin receptor. Vitam Horm 80:51-75

10. Hansen BF, Danielsen GM, Drejer K et al (1996) Sustained signalling from the insulin receptor after stimulation with insulin analogues exhibiting increased mitogenic potency. Biochem $\mathrm{J}$ 315:271-279

11. Berti L, Kellerer M, Bossenmaier B, Seffer E, Seipke G, Haring HU (1998) The long acting human insulin analog HOE 901: characteristics of insulin signalling in comparison to Asp(B10) and regular insulin. Horm Metab Res 30:123-129

12. Milazzo G, Sciacca L, Papa V, Goldfine ID, Vigneri R (1997) ASPB10 insulin induction of increased mitogenic responses and phenotypic changes in human breast epithelial cells: evidence for enhanced interactions with the insulin-like growth factor-I receptor. Mol Carcinog 18:19-25

13. Kurtzhals P, Schaffer L, Sorensen A et al (2000) Correlations of receptor binding and metabolic and mitogenic potencies of insulin analogs designed for clinical use. Diabetes 49:999-1005

14. Dideriksen LH, Jorgensen LN, Drejer K (1992) Carcinogenic effect on female rats after 12 months administration of the insulin analog B10 Asp. Diabetes 41:143A

15. Ebeling P, Tuominen JA, Koivisto VA (1996) Insulin analogues and carcinoma of the breast. Diabetologia 39:124-125

16. Smith U, Gale EA (2009) Does diabetes therapy influence the risk of cancer? Diabetologia 52:1699-1708

17. Mosthaf L, Grako K, Dull TJ, Coussens L, Ullrich A, McClain DA (1990) Functionally distinct insulin receptors generated by tissue-specific alternative splicing. EMBO J 9:2409-2413

18. Belfiore A, Frasca F, Pandini G, Sciacca L, Vigneri R (2009) Insulin receptor isoforms and insulin receptor/insulin-like growth factor receptor hybrids in physiology and disease. Endocr Rev 30:586-623

19. Staiger K, Hennige AM, Staiger H, Haring HU, Kellerer M (2007) Comparison of the mitogenic potency of regular human insulin and its analogue glargine in normal and transformed human breast epithelial cells. Horm Metab Res 39:65-67

20. Shukla A, Grisouard J, Ehemann V, Hermani A, Enzmann H, Mayer D (2009) Analysis of signaling pathways related to cell proliferation stimulated by insulin analogs in human mammary epithelial cell lines. Endocr Relat Cancer 16:429-441

21. Frasca F, Pandini G, Scalia P et al (1999) Insulin receptor isoform A, a newly recognized, high-affinity insulin-like growth factor II receptor in fetal and cancer cells. Mol Cell Biol 19:3278-3288 
22. Taniguchi CM, Emanuelli B, Kahn CR (2006) Critical nodes in signalling pathways: insights into insulin action. Nat Rev Mol Cell Biol 7:85-96

23. Wada T, Azegami M, Sugiyama M, Tsuneki H, Sasaoka T (2008) Characteristics of signalling properties mediated by long-acting insulin analogue glargine and detemir in target cells of insulin. Diabetes Res Clin Pract 81:269-277

24. Sacco A, Morcavallo A, Pandini G, Vigneri R, Belfiore A (2009) Differential signaling activation by insulin and insulin-like growth factors I and II upon binding to insulin receptor isoform A. Endocrinology 150:3594-3602

25. Pandini G, Vigneri R, Costantino A et al (1999) Insulin and insulin-like growth factor-I (IGF-I) receptor overexpression in breast cancers leads to insulin/IGF-I hybrid receptor overexpression: evidence for a second mechanism of IGF-I signaling. Clin Cancer Res 5:1935-1944

26. Ish-Shalom D, Christoffersen CT, Vorwerk P et al (1997) Mitogenic properties of insulin and insulin analogues mediated by the insulin receptor. Diabetologia 40(Suppl 2):S25-S31

27. Chisalita SI, Johansson GS, Liefvendahl E, Back K, Arnqvist HJ (2009) Human aortic smooth muscle cells are insulin resistant at the receptor level but sensitive to IGF1 and IGF2. J Mol Endocrinol 43:231-239

28. Sciacca L, Costantino A, Pandini G et al (1999) Insulin receptor activation by IGF-II in breast cancers: evidence for a new autocrine/paracrine mechanism. Oncogene 18:2471-2479

29. Vella V, Pandini G, Sciacca L et al (2002) A novel autocrine loop involving IGF-II and the insulin receptor isoform-A stimulates growth of thyroid cancer. J Clin Endocrinol Metab 87:245254
30. Erbel S, Reers C, Eckstein VW et al (2008) Proliferation of colo357 pancreatic carcinoma cells and survival of patients with pancreatic carcinoma are not altered by insulin glargine. Diab Care 31:1105-1111

31. Liefvendahl E, Arnqvist HJ (2008) Mitogenic effect of the insulin analogue glargine in malignant cells in comparison with insulin and IGF-I. Horm Metab Res 40:369-374

32. Weinstein D, Simon M, Yehezkel E, Laron Z, Werner H (2009) Insulin analogues display IGF-I-like mitogenic and anti-apoptotic activities in cultured cancer cells. Diabetes Metab Res Rev 25:41-49

33. Bahr M, Kolter T, Seipke G, Eckel J (1997) Growth promoting and metabolic activity of the human insulin analogue [GlyA21, ArgB31, ArgB32]insulin (HOE 901) in muscle cells. Eur J Pharmacol 320:259-265

34. Eckardt K, May C, Koenen M, Eckel J (2007) IGF-1 receptor signalling determines the mitogenic potency of insulin analogues in human smooth muscle cells and fibroblasts. Diabetologia 50:25342543

35. Markussen J, Havelund S, Kurtzhals P et al (1996) Soluble, fatty acid acylated insulins bind to albumin and show protracted action in pigs. Diabetologia 39:281-288

36. Staiger K, Staiger H, Schweitzer MA et al (2005) Insulin and its analogue glargine do not affect viability and proliferation of human coronary artery endothelial and smooth muscle cells. Diabetologia 48:1898-1905

37. Agin A, Jeandidier N, Gasser F, Grucker D, Sapin R (2007) Glargine blood biotransformation: in vitro appraisal with human insulin immunoassay. Diab Metab 33:205-212

38. Garg SK, Hirsch IB, Skyler JS (2009) Insulin glargine and canceran unsubstantiated allegation. Diab Technol Ther 11:473-476 